\title{
Quality of reading among equipment for determining water content in corn kernels
}

\section{Qualidade da leitura entre equipamentos para determinação do teor de água em grãos de milho}

\author{
Thais Caroline Rodrigues ${ }^{1}$; Franciele Morlin Carneiro ${ }^{2 *}$; Rodrigo Garcia Brunini ${ }^{3}$; \\ Patricia Candida de Menezes ${ }^{4}$; Rafael Scabello Bertonha"; \\ Carlos Eduardo Angeli Furlani ${ }^{6}$
}

\begin{abstract}
Highlights:
Incorrect storage compromises the quality of the grain, damage to the producer. Water content sensors result in quick responses to ensure grain quality.

Statistical Quality Control for monitoring agricultural operations.

The water content of the grains is decisive for determining the management.

Losses occur during harvest management, reflecting losses for the producer.
\end{abstract}

\begin{abstract}
Corn productivity in Brazil has been gradually increasing, and adequate storage of produce is a matter of safety; under appropriate storage, the quality of the product is preserved and losses are avoided or minimized. Hence, monitoring temperature and moisture control is essential. The objective of this study was to verify the quality of readings of equipment used to determine the water content of corn seeds according to the sowing times, and to verify the existence of correlations among the equipment. The experiment was conducted at the Research and Extension Teaching Farm (FEPE), which belongs to UNESP/FCAV in Jaboticabal, SP. The experimental design was based on the basic premise of statistical quality control (SQC). Three experimental areas were evaluated with two corn hybrids and with different days after sowing (DAS): Area A (hybrid AS1633PRO2 at 132 DAS), Area B (hybrid AS1555RR2 at 125 DAS), and Area C (hybrid AS1633PRO2 at 150 DAS). To evaluate the water content of the seeds, an expeditious method was employed using two different moisture sensors (Equipment 1 and 2) based on the principle of dielectric measurement (moisture by capacitance). The greenhouse method (Equipment 3 ) was also tested. The highest reading quality was observed in Equipment 1, and Area C showed less variability and a higher average yield because of the adequate physiological maturation points of the harvest and more appropriate grain water content. Equipment 3 and 1 showed better correlation between the evaluations because the calibration of Equipment 1 had readings close to those of the standard method (Equipment 3).
\end{abstract}

Key words: Monitoring. Moisture sensor. Zea mays.

1 Enga Agra ${ }^{\mathrm{a}}$, Discente de MBA de Agronegócio, Escola Superior de Agricultura “Luiz de Queiroz”, ESALQ, Piracicaba, SP, Brasil. E-mail: thais00rodrigues@gmail.com

2 Pós-Doutoranda do Programa de Pós-Graduação em Agronomia, Produção Vegetal, Faculdade de Ciências Agrárias e Veterinárias, Universidade Estadual Paulista, FCAV/UNESP, Jaboticabal, SP, Brasil. E-mail: franmorlin1@gmail.com

3 Prof. Dr., Universidade José do Rosário Vellano, UNIFENAS, Alfenas, MG, Brasil. E-mail: rgbrunini@gmail.com

${ }^{4}$ Prof $^{\mathrm{a}} \mathrm{Dr}^{\mathrm{a}}$, Instituto Federal de Educação, Ciência e Tecnologia de Rondônia, IFRO, Colorado do Oeste, RO, Brasil. E-mail: patricia.menezes@ifro.edu.br

5 Dr., Pesquisador Associado Sênior, Corteva Agriscience, Indianópolis, MG, Brasil. E-mail: rafaelbertonha@gmail.com

6 Prof. Dr., FCAV/UNESP, Jaboticabal, SP, Brasil. E-mail: eduardo.furlani@unesp.br

* Author for correspondence 


\title{
Resumo
}

\begin{abstract}
A produtividade de milho no Brasil vem aumentando gradativamente, e o armazenamento adequado da produção é uma questão de segurança, sendo assim, quando conduzido adequadamente, a qualidade do produto é preservada e as perdas são evitadas ou minimizadas. Assim, o monitoramento, o controle da temperatura e umidade se torna fundamental. Objetivou-se verificar a qualidade da leitura dos equipamentos utilizados para a determinação do teor de água em grãos de milho em função das épocas de semeadura, e também verificar a correlação existente entre os equipamentos. O experimento foi conduzido na Fazenda de Ensino Pesquisa e Extensão (FEPE), pertencente a UNESP/FCAV em Jaboticabal-SP. O delineamento experimental foi baseado nas premissas básicas do Controle Estatístico de Qualidade - CEQ. Foram avaliadas três áreas experimentais com dois híbridos de milho e com diferentes dias após a semeadura, sendo: área A (híbrido AS1633PRO2 aos 132 DAS), área B (híbrido AS1555RR2 aos 125 DAS) e área C (híbrido AS1633PRO2 aos 150 DAS). A fim de avaliar o teor de água dos grãos, foi empregado o método expedito, por meio de sensores de umidade e o método da estufa. Para o método expedito utilizou-se dois sensores que constam de princípio de medição dielétrica (umidade por capacitância). A maior qualidade de leitura foi no Equipamento 1, e a área $\mathrm{C}$ apresentou menor variabilidade, devido aos adequados pontos de maturação fisiológico para a colheita como também ao do teor de água do grão, e também demonstrou média superior de produtividade. Os equipamentos 3 e 1 tiveram melhor correlação nas avaliações, devido a calibração do equipamento 1 ter apresentado leituras próximas ao do método padrão (Equipamento 3).
\end{abstract}

Palavras-chave: Monitoramento. Sensor de umidade. Zea mays.

\section{Introduction}

Incorrect storage compromises the quality and health of maize grains, which directly affects the economy and rural producers (Paraginski, Rockenbach, Santos, Elias, \& Oliveira, 2015). However, good drying and storage of the grains reduces the water content of the cereal to ideal values $(13 \%$ to $15 \%$ moisture), decreasing the chances of grain deterioration and artificially extending the storage period (Magalhães, Durães, Carneiro, \& Paiva, 2002; Devilla, Couto, Zolnier, \& Silva, 2004; Santos, Medina, Lourenção, Parisi, \& Godoy, 2013).

The use of equipment capable of generating quick and more accurate responses is extremely important to ensure the quality and correct storage of corn kernels. One example of such equipment is the grain water content sensor, which can provide immediate results capable of improving producer's decision-making and ensuring that the corn to be sold is of high quality (Ullmann, Resende, Chaves, \& Sousa, 2013).
Using statistical quality control (SQC) tools, it is possible to obtain a detailed description of the behavior of the process, identify its variability, and thus allow its control over time, based on the continuous collection of data and detection of possible causes of change (Lima et al., 2006). The use of these tools contributes to the analysis of variables to guarantee the quality of the process (Silva, Cassia, Voltarelli, Compagnon, \& Furlani, 2013).

To improve operational quality, several authors (e.g., Tavares et al. (2015) in coffee collection, Zerbato, Cavichioli, Raveli, Marrafon and Silva (2013) in mechanized corn harvesting, Cassia, Silva, Paixão, Bertonha and Cavichioli (2014) and Voltarelli, Silva, Cassia, Ortiz and Torres (2015) in sugarcane culture, Chioderoli et al. (2012), and Toledo et al. (2008) and Voltarelli, Silva, Cassia, Ortiz and Torres (2012) in soybean culture) have used SQC to monitor agricultural operations.

The water content of grains is a limiting parameter for determining the management of 
the crop; a part of the grain losses occurs during harvest, which directly impacts the productivity and profitability of the operation and results in direct losses to the producer.

Based on the principles mentioned above, there is a need to avoid loss of grain quality after harvesting. The development of this study was justified by the use of SQC tools to evaluate the quality of grain water content indicators and productivity across space. Thus, the objective of this study was to analyze the quality and accuracy of readings between different equipment used to determine the water content in corn kernels according to the sowing time.

\section{Material and Methods}

The experiment was carried out during the 2015/16 harvest, in the municipality of Jaboticabal, state of São Paulo, in an experimental area of the Research and Extension Teaching Farm (RETF) belonging to UNESP/FCAV. The area has an average altitude of $580 \mathrm{~m}$, a tropical savanna (Aw) climate according to the Köppen classification of climate change (Alvares, Stape, Sentelhas, Gonçalves, \& Sparovek, 2013), an average temperature of 21.7 ${ }^{\circ} \mathrm{C}$, and an average annual rainfall of $1340 \mathrm{~mm}$ (Centurion, 1982). The soils of the experimental areas were classified as eutroferric Red Latosol according to Empresa Brasileira de Pesquisa Agropecuária [EMBRAPA] (2018).

The experimental design was based on the basic premises of the SQC (Montgomery, 2009), evaluating the quality indicators of the water content of the grain and the productivity of the corn crop over time. Three experimental areas, A, B, and $\mathrm{C}$, were evaluated, in which a specific corn hybrid was grown in each area and the evaluations were carried out on different days after sowing (DAS) (Table 1). Forty sample points were evaluated in each experimental area.

Table 1

Characteristics of assessed areas and time of assessments

\begin{tabular}{cccccc}
\hline $\begin{array}{c}\text { Experimental } \\
\text { area }\end{array}$ & Corn hybrid & Hybrid cycle & $\begin{array}{c}\text { Time of } \\
\text { assessments }\end{array}$ & $\begin{array}{c}\text { Size of experimental } \\
\text { area (ha) }\end{array}$ & $\begin{array}{c}\text { Perimeter } \\
(\mathrm{m})\end{array}$ \\
\hline A & AS1633PRO2 & Premature & 132 DAS* & 0.73 & 760.82 \\
B & AS1555RR2 & Premature & 125 DAS & 0.55 & 736.89 \\
C & AS1633PRO2 & Premature & 150 DAS & 0.18 & 540.29 \\
\hline
\end{tabular}

* Days after sowing corn.

During sowing, 5.4 grains of corn per meter were distributed in the experimental areas, with a sowing density of 60,000 grains ha ${ }^{-1}$ and row spacing of 0.90 $\mathrm{m}$. Planting fertilization was carried out together with sowing, in which $300 \mathrm{~kg} \mathrm{ha}^{-1}$ of formulated NPK (08:28:16) was applied. Subsequently, sowing was carried out by covering fertilization using 300 $\mathrm{kg} \mathrm{ha}^{-1}$ of urea 30 days after emergence.
To evaluate the water content of the grains (moisture), an expeditious method with moisture sensors was used, as well as the greenhouse method (Ministério da Agricultura, Pecuária e Abastecimento [MAPA], 2009). For the expeditious method, two sensors were used (Equipment 1 and Equipment 2 [Table 2]), based on the principle of dielectric measurement (humidity by capacitance). 
Table 2

Technical specifications for sensors used to quantify the water content of corn kernels

\begin{tabular}{cccccc}
\hline Sensor & Equipment & Brand & Model & Precision & Measuring scale \\
\hline Expeditious method & 1 & GehakaAgri & G600 & $0.5 \%$ & $5 \%-40 \%$ \\
Expeditious method & 2 & Bett & PM 300 & $0.2 \%-0.5 \%$ & $6 \%-40 \%$ \\
Greenhouse method & 3 & Marconi & MA 35 & - & - \\
\hline
\end{tabular}

The weights of the samples were determined for later reading of the water content, according to the manufacturer's recommendations for each sensor. For Equipment 3 (greenhouse under air circulation), the standard method was applied, where the grain was kept for $24 \mathrm{~h}$ in controlled heating at $105 \pm 3$ ${ }^{\circ} \mathrm{C}$. To obtain the results, equipment (3) was used as a reference for the calibration of Equipment 1 and 2.

During the harvest season for each specific experimental area, plants were sampled at 40 random points, and ears were harvested manually and submitted to a mechanical track to separate the grains. Then, the grains were weighed on a digital scale (Model BL 3200H). The values obtained were converted to $\mathrm{kg} \mathrm{ha}^{-1}$ and productivity was corrected to $13 \%$ humidity (Furlani, Canova, Cavichioli, Bertonha, \& Silva, 2013).

To perform the reading of Equipment 1 and 2, the same corn kernels were used, and the productivities and their values were calculated in relation to the standard greenhouse method (Equipment 3).

The quality indicators used were productivity $(\mathrm{kg}$ $\left.\mathrm{ha}^{-1}\right)$, grain water content (\%), accuracy between the sensor readings, and accuracy between the sensors depending on the sowing time.

For statistical analysis of the quality indicators, a statistical process control (SPC) tool was used through charts of individual value and mobile range control.

The lower (LCL) and upper (UCL) control limits were determined according to the variability of the process and were calculated with a mean of more or less three times the standard deviation. When the calculated value of the LCL was negative, LCL was considered null $(\mathrm{LCL}=0$ ) (Montgomery, 2009; Noronha, Silva, Chioderoli, Santos, \& Cassia, 2011; Silva, Voltarelli, Cassia, Vidal, \& Cavichioli, 2014).

The Pearson correlation coefficient $(r)$ varied from -1 to 1 . The sign indicates a positive or negative direction of the relationship, and the value suggests the strength of the relationship between the variables (Figueiredo, \& Silva, 2009).

Dancey and Reidy (2005) developed a classification for the relationship between the variables: $r=0.10$ to 0.30 (weak); $r=0.40$ to 0.6 (moderate); $r=0.70$ to 1 (strong). According to the same authors, the closer to 1 (regardless of the sign), the greater the degree of linear statistical dependence between the variables; however, the closer to zero, the lower the strength of this relationship.

\section{Results and Discussion}

According to Figure 1, for the chart of individual value control, Area $\mathrm{C}$ presented less variability according to the three analyses of the grain water content in each equipment used $(1,2$, and 3$)$.

For Area C, only Equipment 3 (greenhouse) presented an out-of-control point motivated by a special cause, such as very dry grain or even error at the point or moment of harvest, which was detected as an outlier (outlier point outside the curve), since the water content of the harvested grain was above the values for the other measured grains.

The out-of-control points caused by the action of special causes may have occurred due to several 
reasons, including harvest time, physiological maturation according to the point of harvest, precision in reading the equipment, and a less than appropriate water content of the grains, among others.

For the three equipment methods evaluated, Area $\mathrm{C}$ showed less dispersion and a higher quality in the reading of the data, demonstrating grain water content values suitable for harvest. According to Magalhães et al. (2002), the point of physiological maturity characterizes the ideal moment for the harvest or point of maximum production, since it should have values between $13 \%$ and $15 \%$ humidity to avoid problems with storage.
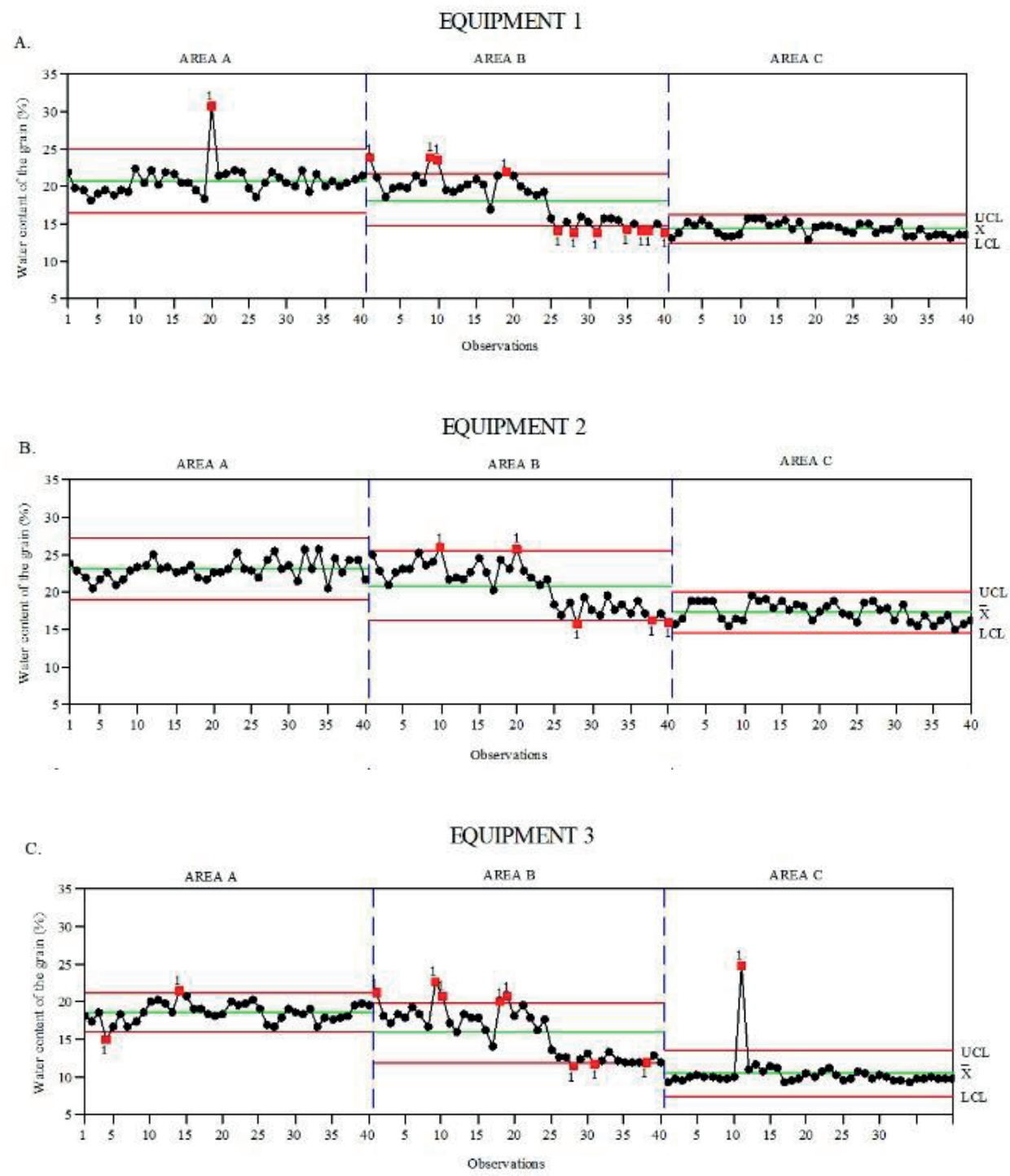

Figure 1. Control cards of individual values to verify the reading qualities of Equipment 1, 2, and 3, according to the sowing time of the three corn areas (A, B, and C) evaluated

UCL: upper control limit;: average of individual values; LCL: lower control limit. 
The sowing season is related to the physiological maturity of the crop. Areas A and B, which were harvested before their ideal maturation point, had significant and high results in relation to the water content of the grain (Figure 1), which were around $18 \%$ and $20 \%$ moisture, respectively; it was observed that this directly affected crop productivity.

Monteiro (2008) highlights the importance of assessing the water content in the grains, as significant losses occur during harvest management, directly impacting the productivity and causing losses for the producer.

Morse, Lindt, Oelke, Brandon and Curley (1967), Webb (1980), and Luh and Mickus (1980) verified that an excessive number of immature grains is also produced because of the uneven maturation of the cultivars; grains with poor appearance are weaker and break during processing. The authors also confirmed that grains harvested before full maturation are lighter, poorly formed, and less vigorous, with negative effects on storage and after planting, which is not practical for the producer. As noted by Höfs, Postal and Nesi (2016), the harvest is considered to be one of the most relevant phases for the corn grain production system; the removal of grains from the field in good condition for further procedures, such as drying, processing, and sowing, is of paramount importance for the next harvest and preserving their quality through post-harvest care.

In Figure 2A, it can be seen in the individual value control charts that when evaluating Area A, Equipment 3 obtained less variable and higher quality data. For Area B (Figure 2B), it was noted that there was greater variability in the comparative assessment of equipment reading accuracy and points of action for special causes (highlighted in red). The values obtained with Equipment 1, 2, and 3 were similar, with results and variations close to each other. Equipment 1 (Figure 2) obtained less variability between the assessments of areas, despite presenting some out-of-control points, which may have been caused by the high water content in the corn kernels due to the harvest in areas A and B having been carried out before the maturation point. This shows that the highest quality readings were performed by this equipment.

A.

Area A

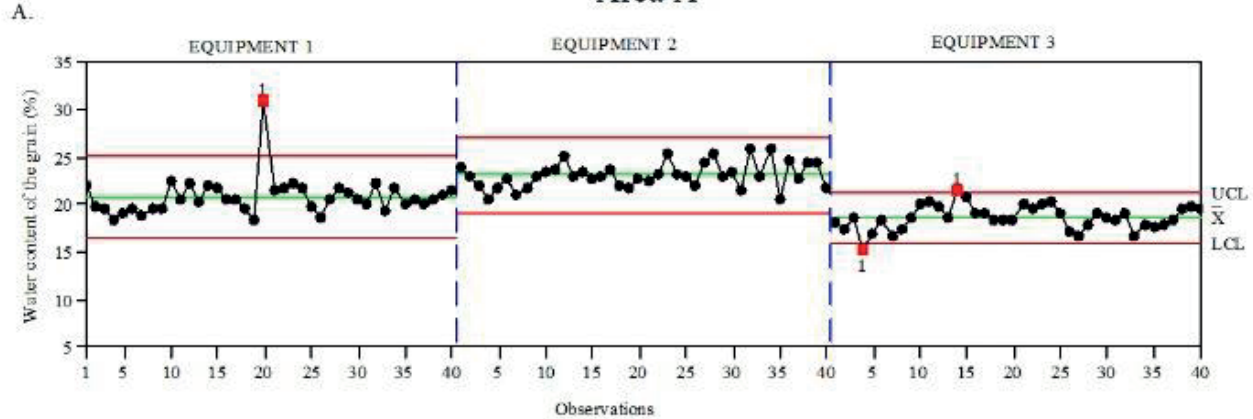

Area B

B.

EQUIPMENT 2 EQUIPMENT 3

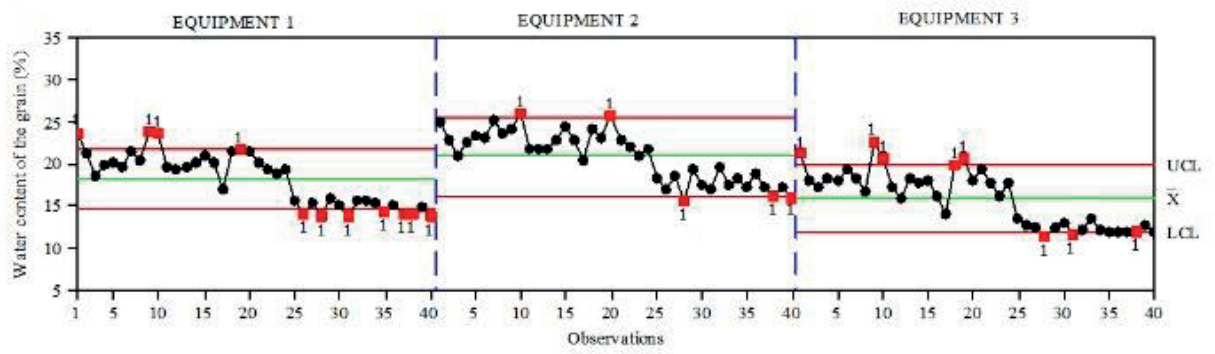




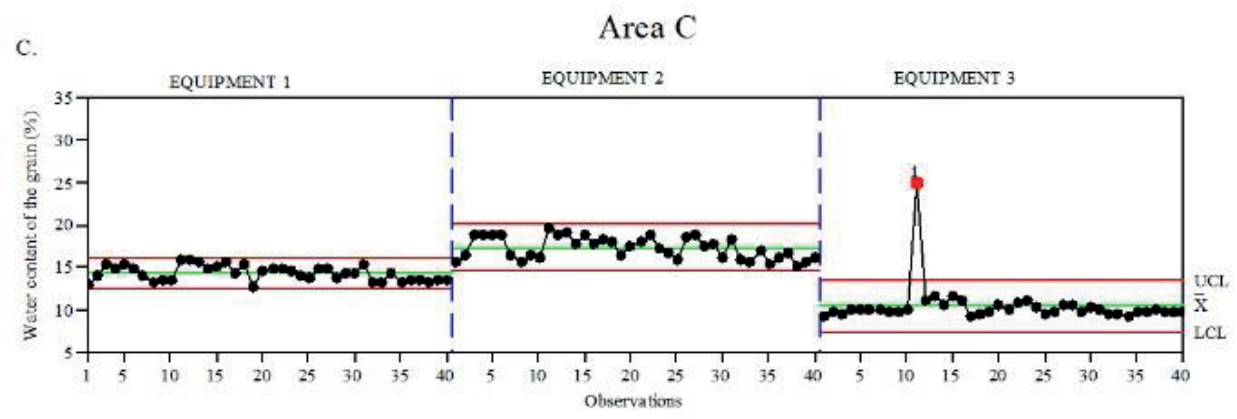

Figure 2. Individual value control charts for the three areas (A, B and C) sown with corn at different times depending on the reading qualities of Equipment 1,2, and 3

UCL: upper control limit;: average of individual values; LCL: lower control limit.

Equipment 3 presented a lower number of special points; this is attributed to the fact that the standard method of quantifying the water content was used for this equipment. However, there was a greater dispersion of data in terms of amplitude than in Equipment 1 (Figure 2).

According to the data from Area C, Equipment 1 obtained the greatest accuracy, owing to the better quality of the data reading process. In general, it is observed that Equipment 1 showed the highest quality readings, which was verified in the individual value charts for the areas evaluated at different sowing times for the corn crop.

In accordance with data from the USDA (United States Department of Agriculture [USDA], 2017) and research conducted by Rachaputi (2010), accurate water content measurement is essential in the commercialization, storage, and processing of corn; such characteristics increase the producer's gains, as can be seen in the data from Equipment 3: as it has a more adequate crop water content, better results were also obtained in terms of productivity (Figure 2). Storing grains with a higher water content increases the risk of microbial growth and can increase aflatoxin contamination during storage.

In Figure $3 \mathrm{~A}$ and $\mathrm{B}$, it was possible to verify the productivity (in $\mathrm{kg} \mathrm{ha}^{-1}$ ) and mobile amplitude obtained for each sowed area. Area C (Figure 3A) presented higher productivity $\left(8,675 \mathrm{~kg} \mathrm{ha}^{-1}\right)$ than did areas $\mathrm{A}$ and $\mathrm{B}\left(7,151\right.$ and $\left.7,449 \mathrm{~kg} \mathrm{ha}^{-1}\right)$. This can be explained by the better development of the corn grains; they had a more adequate water content (14\%) and ideal physiological maturation. 

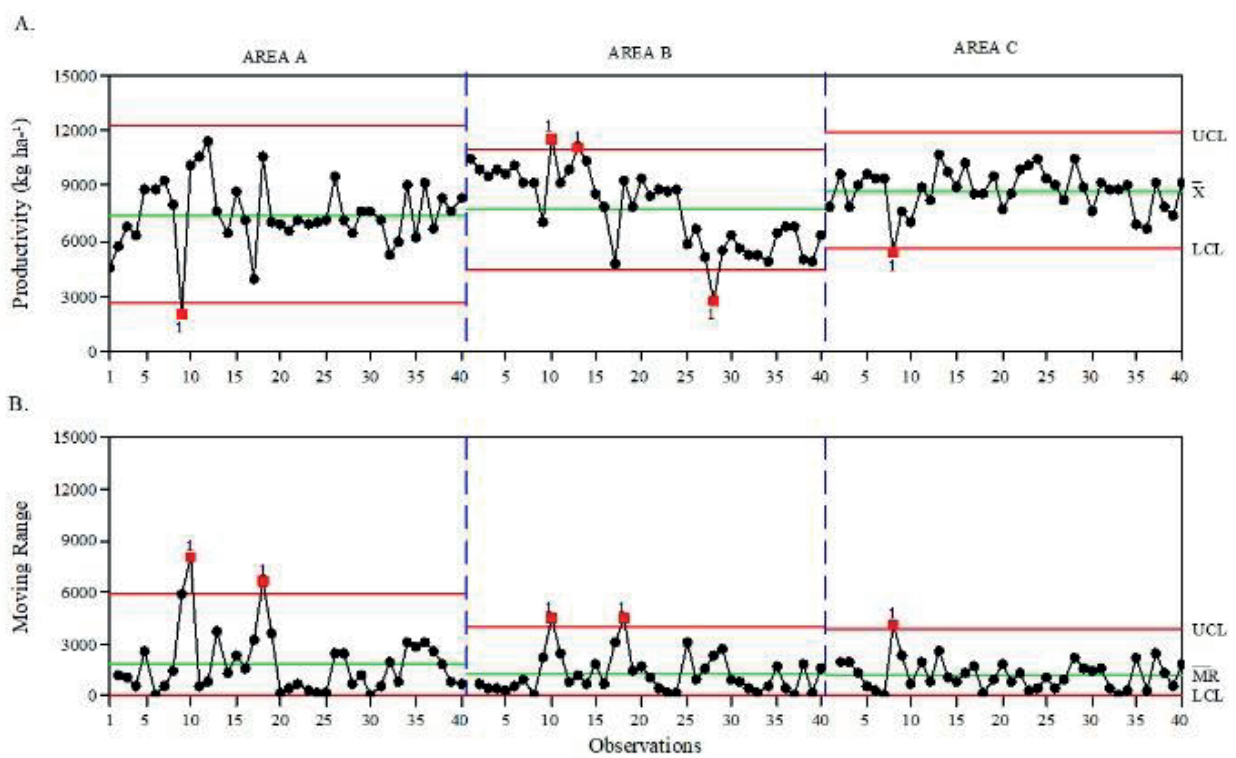

Figure 3. Control charts of individual values (A) and mobile ranges (B) for the productivities of areas $\mathrm{A}, \mathrm{B}$, and $\mathrm{C}$ cultivated with corn at different sowing seasons UCL: upper control limit;: average of individual values; USL: upper specific limit; LSL: lower specific limit; LCL: lower control limit; : average of individual values.

Even with the out-of-control points, the greenhouse method showed a higher process quality. Raschen et al. (2014) noted that despite being easy to perform, this method requires a longer time for evaluation than do the other methods; it takes about $24 \mathrm{~h}$ of heating, usually at $105{ }^{\circ} \mathrm{C}$, to obtain the result.

The charts of individual values and mobile ranges (Figure 3A and $\mathrm{B}$ ) for the productivity indicators of areas $\mathrm{A}, \mathrm{B}$, and $\mathrm{C}$ showed less variability in water content sensor readings in Area C. This result was due to the time of evaluation, demonstrating the importance of the maturation process, grain water content, and harvest period.

Corroborating with Pedroso et al. (2008), who confirmed that starting from the proper maturation point, there tends to be a reduction in the quality of the grains, which highlights the importance of harvesting in the correct season. The speed of deterioration is influenced by environmental factors, especially those prevalent in the final stage of maturation. According to Barbedo and Marcos (2013), grain technologists should consider the point of maximum vigor as the most suitable time for harvest, being delimited by the development and maturation of grains.

In Table 3, according to the classification by Dancey and Raicy (2006), Pearson's correlation coefficient $(r)$ was weak between the equipment in Area A. In the evaluation of Area B, the values showed a strong correlation, and in Area C, they ranged between a strong and moderate correlation. 
Table 3

Pearson's correlation coefficient for equipment as a function of sowing season

\begin{tabular}{|c|c|c|c|}
\hline \multicolumn{4}{|c|}{ Area A } \\
\hline & Equipment 1 & Equipment 2 & Equipment 3 \\
\hline Equipment 1 & - & $0.360^{*}$ & $0.372^{*}$ \\
\hline Equipment 2 & & - & $0.344^{*}$ \\
\hline Equipment 3 & & & - \\
\hline \multicolumn{4}{|c|}{ Area B } \\
\hline Equipment 1 & - & $0.966^{* *}$ & $0.966^{* *}$ \\
\hline Equipment 2 & & - & $0.907^{* *}$ \\
\hline Equipment 3 & & & - \\
\hline \multicolumn{4}{|c|}{ Area C } \\
\hline Equipment 1 & - & $0.899^{* *}$ & $0.411^{* *}$ \\
\hline Equipment 2 & & - & $0.398^{*}$ \\
\hline Equipment 3 & & & - \\
\hline
\end{tabular}

* Significant at $5 \%$ probability; ** significant at $1 \%$ probability; ns: Not significant.

Barbetta, Reis and Bornia (2004) and Ferreira (2009) observed that with Pearson's correlation coefficient, it is possible to measure the intensity, strength, or degree of linear association between two random variables. In the present study, it can be seen that the values of the coefficients between Equipment 3 and 1 had a better correlation in the evaluations; this is due to the calibration of Equipment 1 having readings close to those of the standard method (Equipment 3), and showing greater quality than those of Equipment 2.

Cargnelutti, Toebe, Burin, Silveira and Casarotto (2010) observed the use of Pearson's correlation coefficient in other studies, including those on corn, and highlighted how important it is to enable the accurate estimation of correlation coefficients, which are widely used in studies of linear relationships.

\section{Conclusions}

Area $\mathrm{C}$ showed less variability in the analyzed data, and it showed a higher average productivity than the other areas.
Equipment 1 (expeditious method) showed the highest quality in the reading of the water content of the corn kernels.

Equipment 3 and 1 showed better correlation in the evaluations, owing to the calibration of Equipment 1 having readings close to those of the standard method (Equipment 3).

There were significant differences in productivity depending on the sowing season and grain maturation period.

\section{References}

Alvares, C. A., Stape, J. L., Sentelhas, P. C., Gonçalves, J. L. de M., \& Sparovek, G. (2013). Köppen's climate classification map for Brazil. Meteorologische Zeitschrift, 22(6), 711-728. doi: 10.1127/09412948/2013/0507

Barbedo, C. J., \& Marcos, J., Fo. (2013). Tolerância à dessecação em sementes. Acta Botânica Brasilica, 12(2), 145-164. doi: 10.1590/S010233061998000200005

Barbetta, P. A., Reis, M. M., \& Bornia, A. C. (2004). Estatística para cursos de engenharia e informática. São Paulo: Atlas. 
Cargnelutti, A., F'., Toebe, M., Burin, C., Silveira, T. R. da, \& Casarotto, G. (2010). Tamanho de amostra para estimação do coeficiente de correlação linear de Pearson entre caracteres de milho. Pesquisa Agropecuária Brasileira, 45(12), 1363-1371. doi: 10.1590/S1806-66902011000100019

Cassia, M. T., Silva, R. P. da, Paixão, C. S. S., Bertonha, R. S., \& Cavichioli, F. A. (2014). Desgaste das facas do corte basal na qualidade da colheita mecanizada de cana-de-açúcar. Ciência Rural, 44(6), 987-993. doi: 10.1590/S0103-84782014000600006

Centurion, J. F. (1982). Balanço hídrico da região de Ilha Solteira. Científica, 10(1), 57-61. Recuperado de http://cientifica.org.br/index.php/cientifica

Chioderoli, C. A., Silva, R. P. da, Noronha, R. H. de F., Cassia, M. T., \& Santos, E. P. dos. (2012). Perdas de sementes e distribuição de palha na colheita mecanizada de soja. Bragantia, 71(1), 112-121. doi: 10.1590/S0006-87052012005000003

Dancey, C., \& Reidy, J. (2005). Estatística sem matemática para psicologia: usando SPSS para Windows. Porto Alegre: Artmed.

Devilla, I. A., Couto, S. M., Zolnier, S., \& Silva, J. de S. e. (2004). Variação da temperatura e umidade de sementes armazenados em silos com aeração. Revista Brasileira de Engenharia Agrícola e Ambiental, 8(23), 284-291. doi: 10.1590/S1415-

Empresa Brasileira de Pesquisa Agropecuária (2018). Sistema brasileiro de classificação de solos (5a ed. rev. amp.). Brasília: EMBRAPA.

Ferreira, D. F. (2009). Estatística básica (2a ed.). Lavras: UFLA.

Figueiredo, D. B., Fo ., \& Silva, J. A. (2009). Desvendando os mistérios do coeficiente de correlação de pearson (r). Revista Política Hoje, 18(1), 115-146. Recuperado de http://periodicos.ufpe.br/revistas/ politicahoje/article/view/3852/3156

Furlani, C. E. A., Canova, R., Cavichioli, F. A., Bertonha, R. S., \& Silva, R. P. da. (2013). Demanda energética por semeadora-adubadora em função da haste sulcadora na semeadura do milho. Revista Ceres, 60(6), 885-889. doi: 10.1590/S0034$737 \mathrm{X} 2013000600017$

Höfs, A., Postal, M., \& Nesi, C. N. (2016). A qualidade das sementes de milho em diferentes formas de colheita e beneficiamento. Anais do Congresso Nacional de Milho e Sorgo, Bento Gonçalves, RS, Brasil, 31. Recuperado de http://www.abms.org.br/ cnms2016/anais/trabalhos_por_area/cnms2016_ tecnologia_de_sementes.pdf
Lima, A. A. N, Lima, J. R., Silva, J. L., Alencar, J. R. B., Soares Sobrinho, J. L., Lima, L. G., Rolim-Neto, P. J. (2006). The application of statistical process control to the pharmaceutical industry. Revista de Ciências Farmacêuticas Básica e Aplicada. 27(3):17787. Recuperado de http://www.researchgate.net/ publication/286111629_The_application_of statistical_process_control_to_the_pharmaceutical_ industry

Luh, B. S., \& Mickus, R. R. (1980). Parboiled rice. In B. S. Luh (Ed.), Rice: production and utilization (Cap. 4., pp. 470-507). Westport: CTAVI.

Magalhães, P. C., Durães, F. O. M., Carneiro, N. P., \& Paiva, E. (2002). Fisiologia do milho. (Circular Técnica, 22). Sete Lagoas: EMBRAPA-CNPMS.

Ministério da Agricultura, Pecuária e Abastecimento (2009). Regras para análise de sementes. Brasília: Mapa/ACS.

Monteiro, J. C. (2008). A cultura do milho. Umidade e armazenamento. Sete Lagoas: EMBRAPA-CNPMS. Circular Técnica, 76.

Montgomery, D. C. (2009). Introduction to statistical quality control (3a ed.). New York: John Wiley \& Sons.

Morse, M. D., Lindt, J. H., Oelke, E. A., Brandon, M. D., \& Curley, R. G. (1967). The effect of grain moisture at time of harvest on yield and milling quality of rice. Rice Journal, 70(11), 16-20. Recuperado de http:// thericejournal.springeropen.com/

Noronha, R. H. de F., Silva, R. P. da, Chioderoli, C. A., Santos, E. P. dos, \& Cassia, M. T. (2011). Controle estatístico aplicado ao processo de colheita mecanizada diurna e noturna de cana-de-açúcar. Bragantia, 70(4), 931-938. doi: 10.1590/S000687052011000400028

Paraginski, R. T., Rockenbach, B. A., Santos, R. D., Elias, M. C., \& Oliveira, M. D. (2015). Qualidade de sementes de milho armazenados em diferentes temperaturas. Revista Brasileira de Engenharia Agrícola e Ambiental, 19(4), 358-363. doi: 10.1590/1807-1929/agriambi.v19n4p358-363

Pedroso, D. C., Menezes, V. O., Muniz, M. F. B., Bellé, R., Blume, E., \& Garcia, D. C. (2008). Qualidade fisiológica e sanitária de sementes de Zinnia elegans Jacq. colhidas em diferentes épocas. Revista Brasileira de Sementes, Londrina, 30(3), 164-171. doi: 10.1590/S0101-31222008000300022

Rachaputi, R. (2010). Indústrias primárias e pescas. Camberra, Austrália: ACIAR. Recuperado de http:// era.daf.qld.gov.au 
Raschen, M. R., Lucion, F. B., Cichoski, A. J., Menezes, C. R. de, Wagner, R., Lopes, E. J., Zepka, L. Q., Barin J. S. (2014). Determinação do teor de umidade em sementes empregando radiação micro-ondas. Ciência Rural, 44(5), 925-930. doi: 10.1590/S010384782014000500026

Santos, F., Medina, P. F., Lourenção, A. L., Parisi, J. J. D., \& Godoy, I. J. (2013). Qualidade de sementes de amendoim armazenadas no estado de São Paulo. Bragantia, 72(3), 310-317. doi: 10.1590/ brag.2013.029

Silva, R. P. da, Cassia, M. T., Voltarelli, M.A., Compagnon, A. M., \& Furlani, C. E. A. (2013). Qualidade da colheita mecanizada de feijão (Phaseolus vulgaris) em dois sistemas de preparo do solo. Revista Ciência Agronômica, 44(1), 61-69. Recuperado de http:// www.ccarevista.ufc.br/seer/index.php/ ccarevista/ article/view/1936

Silva, R. P. da, Voltarelli, M. A., Cassia, M. T., Vidal, D. O., \& Cavichioli, F. A. (2014). Qualidade das operações de preparo reduzido do solo e transplantio mecanizado de mudas de café. Coffee Science, Lavras, 9(1), 51-60. Recuperado de http://www. sbicafe.ufv.br:80/handle/123456789/8015

Tavares, T. de O., Santinato, F., Silva, R. P. da, Voltarelli, M. A., Paixão, C. S. S., \& Santinato, R. (2015). Qualidade do recolhimento mecanizado do café. Coffee Science, 10(4), 455-463. doi: 80/ handle/123456789/8148

Toledo, A. de, Tabile, R. A., Silva, R. P. da, Furlani, C. E. A., Magalhães, S. C., \& Costa, B. O. (2008). Caracterização das perdas e distribuição de cobertura vegetal em colheita mecanizada de soja. Engenharia Agrícola, 28(4), 710-719. doi: 10.1590/S010069162008000400011
Ullmann, R., Resende, O., Chaves, T. H., \& Sousa, K. A. de. (2013). Efeito do sistema de exaustão na qualidade do milho armazenado em silos metálicos. Global Science and Technology, 6(2), 102-113.

United States Department of Agricultura (2017). Farmers stock peanuts: inspection instructions. Washington: USDA. Recuperado de https://www.ams.usda. gov/sites/default/files/media/FarmersStock PeanutsInspectionInstructions.pdf

Voltarelli, M. A., Silva, R. P. da, Cassia, M. T., Ortiz, D. F., \& Torres, L. S. (2015). Qualidade do corte basal de cana-de-açúcar utilizando-se de três modelos de facas. Engenharia Agrícola, 35(3), 528-541. doi: 10.1590/1809-4430-Eng.Agric. v35n3p528-541/2015 .

Webb, B. D. (1980). Rice quality and grades. In B. S. Luh (Ed.), Rice: production and utilization (Cap.5, pp. 508-538). Westport: CTAVI.

Zerbato, C., Cavichioli, F. A., Raveli, M. B., Marrafon, M., \& Silva, R. P. da. (2013). Controle estatístico de processo aplicado à colheita mecanizada de milho. Engenharia na Agricultura, 21(3), 261270. Recuperado de http://www.researchgate.net/ publication/273240203_Controle_Estatistico_de Processo_Aplicado_a_Colheita_Mecanizada_de_ Milho 
